\title{
曳行白金クラッド陽極を用いた就行船の電気防食*
}

\section{Cathodic Protection of an Active Ship Using a Trailing Platinum-Clad Anode}

\author{
H.S. Preiser and F.E. Cook**
}

Corrosion, Vol. 13, No.2, 125t 131t (1957) Feb.

\section{粕}

電気防食法の電流分布は若干の要素に左右されるが, その中で重要なのは有効電位差, 陽極および陰極形状, 距離, 電解質の伝導度等である。就行船の船体下部に電 気防食方式を計画するときに防食技術者は船体取付用陽 極を用いて均一な電流密度を得ることに苦労する。大洋 の海水が一定の高伝導度を持っていることは良好な電流 分布を得るのに好都合である。防食技術者は陽極の形状 と有効電位差については広範囲に調節できるが陽極と陰 極の間隔に関しては大きな制限を受ける。

\section{使 用 概 略}

電流分布の問題を改善するためにいろいろの陽極形状 と配置が試みられた。その一つは 30 個の亜鉛陽極 $\left(12^{\prime \prime}\right.$ $\left.\times 6^{\prime \prime} \times 11_{4}^{1 \prime \prime}\right)$ を工廠の曳船に広い間隔で取付けたもので この配置は船体表面に平均した電位を与えることを示し た1)。る5一つは $\mathrm{Mg}$ 陽極（亜鉛より有効電位差大）を ビルジキールに集めて船体と絶縁して取付け加減抵抗を 通して結線しこれを調節して電流出力が船体に対して均 等な分極を合理的に起させるようにした2),3)。他の研究 者達は高電位強電流陽極を使用することによって電流分 布を拡げることに成功した。それは陽極のおのおのの側 に数 $\mathrm{ft}$ にわたり拡がっている電気絶縁物に取付けられ だ,5)。比較的少数の陽極が船体に沿って広い間隔で取 付けられた。この絶縁物は船体からある限定された距離 だけ陽極を移動するのと同じ効果を持つ。Shepard と (Graeser ${ }^{6}$ ( は陽極と陰極の距離が増加するに従って接地 抵抗が対数的に増大することを明らかにした。曲線は陽 極々陰極の距離が陽極直径の 500 倍以上になると漸近線 的に一定抵抗值に近づくことを示す。一般的に絶縁物は わずかばかり陰極と陽極を隔てるだけであり直径の 500 倍に比べればはるかに少ない。ゆえに絶縁物は陽極のす ぐ傍にある陰極での高い電流密度を減じ電流消耗を減ず るけれども, 形の不規則な院極に対する最好適な電流分 布は陰極から陽極を遠く離して置くことによってのみ得 られる。他の重要な事柄は陽極形状について直径と長さ の割合が遠方に設置された陽極の接地抵抗減少の大きな 要素となることである。長さ 48in, 直径 $1 / 4$ in（比 196

* 訳者 花田政明-玉利昭一 日本防蝕工業株式会社

** Bureau of Ships, U.S. Navy Department
：1）の陽極は Dwight の式によって計算したときに約 $0.2 \Omega$ の遠隔地に対する接地抵抗を持つ。

\section{技術的因難}

以上述べたうち今日用いられているすべての方法はい ずれるなんらかの電気防食方式として技術的な困難を持 っている。大量の流電陽極は嵩が張るので経費もかさむ 上に船に無駄な重量と摩擦抵抗を増す。 $\mathrm{Mg}$ 陽極の出力 を抵抗で調節することは陽極腐食率を減じ従って貴重な 陽極材料を無駄に消耗する。高電位陽極は一般に完全な 塗膜を破壞しそのために船体防食電流所要量を增す。高 電位陽極の周囲に電気絶縁物を使うことは, たと之適当 に行われたとしてる費用と時間がかかる。一般に船体取 付電気防食方式は船が乾船渠にある間に船に適した多数 の陽極を取付ける必要がある。この方式では就役中の検 查や保守が簡単にできないで面倒な上に費用もかかるか ら恐らく不可能近い。

\section{困 難 の 克 服}

船体電気防食法の装置々保守の困難性は実施法の変化 と同時に电行陽極の使用により克服することができる。 船体から陽極を適当に離し, 軽い流線型高性能の 1 本の 陽極にまとめると，陽極を船体から十分離れた距離に电 行し, 遠隔点に対する接地抵抗を得ることができる。こ れは本質的に船体のすべての部分に均一な電流通路を作 る。Edison ( はそのような陽極の設計を試みたが適当な 物質がなかったため成功しなかった。白金クラッディング の知識と特殊ヶーブル封縅技術がある現在では簡単な高 性能の史行不溶性陽極は可能でありかつ実際的である。

\section{电行陽極の說明}

曳行陽極は長さ 48 in で銀貨合金棒に 90-10 白金-パ ラジゥム合金クラッドを施したものである。他の物質も 銀の代りに用いられるかもしれない。陽極の主要部分は $1 / 4$ in の直径を有するがその一端で直径が $1 / 2$ inまで次第 にひろがる。

このひろがった端に導線を取付けた上絶縁を完全にし て流線型に仕上げた。陽極棒の他の端は銀鉳を適当につ けた白金合金のゆび炈き状の冠を押し込み，その接合を 十分に保護するためにポリェステル樹脂スリーブをゆび ぬき状の冠の上にかぶせた。厚さ $5 \mathrm{mil}$ のクラット陽極 は $3 \%$ 食塩水中で陽極的に高い電流を $24 \mathrm{hr}$ 通じ $48 \mathrm{hr}$ 
濃硝酸に浸し試験され絶対に孔があかないことが確かめ られた。第 1 図は陽極装置とケープル封縅剂の解説図で

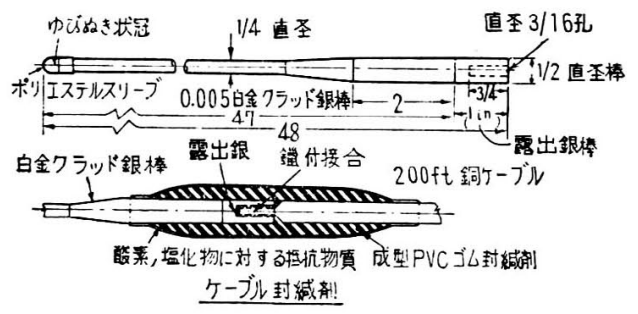

第 1 図曳行白金クラッド陽極

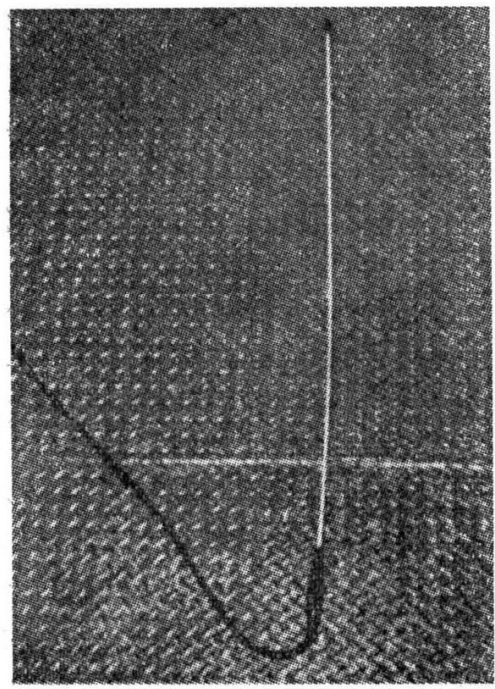

第 2 図 白金クラッド陽極の全貌 成型コムケーブル結合に注意

第 2 図は陽極全体の写真である。ケーブルは PVC で被 覆した長さ約 $200 \mathrm{ft}$ の柔軟な単線であり銀棒に銀で鎦付 㚈して接着する。連続的な激しい使用に対しては鉄心絶 縁銅ケーブルがより型銅線に代用されるであろう。結合 点でケープルと白金クラッド棒の上を流線型の PVC ゴ ム封縅剤を用いて成型する。封縅剂はそれからポリエチ レンテープか酸素, 塩化物に対する抵抗物質でつつまれ る。ここに記載した実験のために封縅剤は順次 PVC 成 型ゴム膜でおおった成型エポキシ樹脂で作られている。 $200 \mathrm{ft}$ の電線の抵抗を含む $(0.2 \Omega)$ 陽極棒の遠方に対す る計算総接地抵抗は $0.4 \Omega$ 程度でありそれは使用中の陽 極電流出力一有効電圧図によって確かめられた。急に動 いたりねじれたり浮動したりせず滑かに引張れる曳行陽 極を得るために設計にはかなりの考慮が払われた。陽極 棒の $\mathrm{ft}$ 当りの重さをケーブルの $\mathrm{ft}$ 当りの重さに近づけ その断面で急激な変化をしないように設計することによ って曳行ヶーブルの延長線に陽極が取付け得るならば, それは一定船速に対して一定の深さで电行され船の速度 が変れば新しいきまった哚さをとるであろう。ケーブル
の結合点は流線形にできているから水はこの円筒に添っ て滑らかに流れ，流れの方向がふらついてばたばたする ようなことがない。

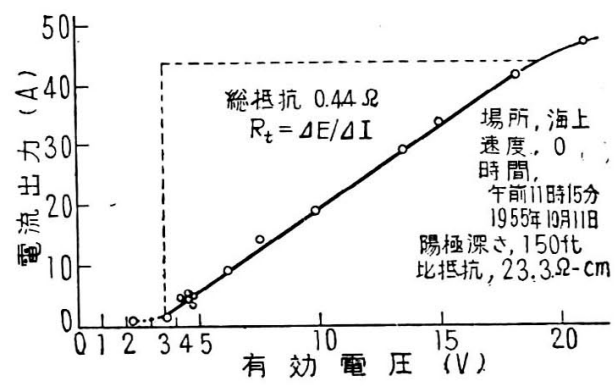

第3 図 曳行白金クラッド陽極に対する電流出 力一有効電圧

\section{初期の实験}

1955年 2 月就行工裔曳船 Y. T. B. 366 亿対し曳行白金 陽極を用いて最初の試験が行われた9)。この実験にとっ て不幸にも曳船の船尾に正常に取り付けられた亜鉛陽極 が 1955 年 1 月に更新され通電前船体の電位は平均約 ー0.78Vであった。この船に対し曳行陽極から通電した 結果は船渠で船体を $-0.85 \mathrm{~V}$ に分極させるためにはわ ずか $2.1 \mathrm{~A}$ でよく 12 ノットで航行中は $4.2 \mathrm{~A}$ 必要とす ることを示した。 $-0.85 \mathrm{~V}$ の電位は完全防食の水準とし て任意に選んだものである。実際の場合には $-0.82 \mathrm{~V}$ までの分極が適当である。Y.T.B. 366 は水線下の面積 約 $1,800 \mathrm{ft}^{2}$ であり約 $90 \mathrm{ft}^{2}$ の $\mathrm{Mn}$ 青銅プロペラを持 つ。曳行陽極から通電するに先だって最初の船体電位デ 一タが相当な分極を示したためにこの試験は適当と思わ れなかった。再び未分極船を用いて試験を行う準備がな された。

\section{最近の实 験}

1955年10月初期, 他の船が実験を繰返すために用いら

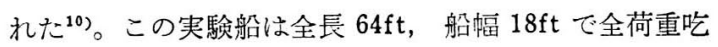
水 $6 \mathrm{ft} 2 \mathrm{in}$ である。その水線下の面積は $1,065 \mathrm{ft}^{2}$ と算 定され Mn 青銅プロペラの面積は $21.8 \mathrm{ft}^{2}$ である。船は 1954年に海軍コールドプラスチック系塗料で最後に塗装 されドックでの観察では底部に中位の污損が見られた。

\section{装}

船には 4 本の銀-塩化銀基準電極を用 意した。 2 本の 固定円盤型基準電極はパイプ支持物に吊し 1 本は右舷側 前方にも5 1 本は左舷側船尾に固定した。なお 2 本の电 行基準電極を船尾に 50ft ケーブル導 線をつけて装 備し た。第 4 図は二つの型の使用基準電極の外観を示す。曳 行陽極は $200 \mathrm{ft}$ のケーブル導線で船尾に取付けた。第 5 困は基华電極と曳行陽極との装置略図である。基準電極 の導線は選択スイッチにつながれそれは順次に電位差計 に接続された。曳行白金クラット陽極は大容量の可変抵 


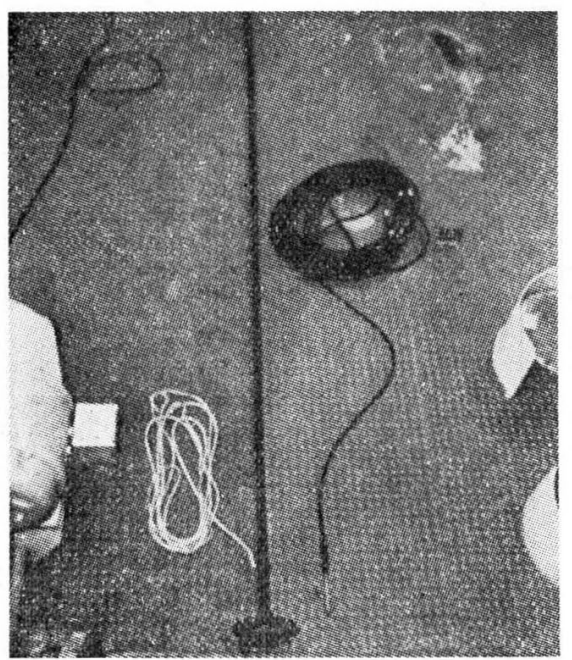

第4図 円盤（左）と曳行（右） $\mathrm{Ag}-\mathrm{AgCl}$ 基準電極

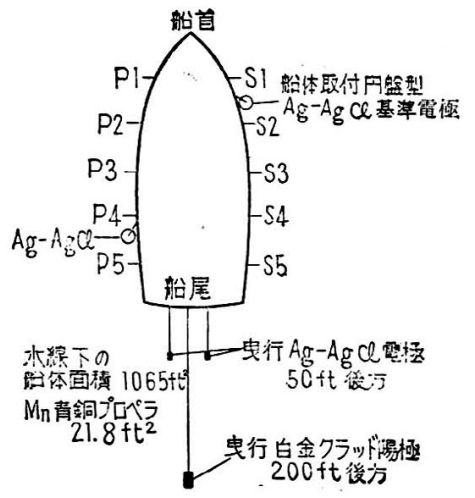

第 5 図曳行白金クラッド陽極の配置図

抗器を通じて船舶用直流発電機に接続した。

\section{ドック試験}

第 1 回試験: 1955年10月6 日予備試験を行った。試験 の目的は遠方に設置した白金クラッド陽極から流れる電 流に対して船の分極反応と復極反応の時間を決定するこ

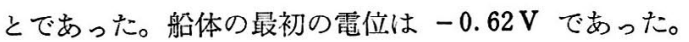
$4.6 \mathrm{~V}$ の有効電圧で $10 \mathrm{~A}$ の電流が船から $200 \mathrm{ft}$ 離れた

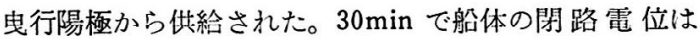
ー0.85Vになった。そして電流を切ったときは速かに低 下した。第 6 図はこれらの電位-時間図である。10A の
電流を流すと船体は急速に分極反応を起しそれは供給電 流があたりまえに必要とする以上であることを示した。 ここに示すように一時的な分極が得られ陽極からの電流 が切られたときは船体の速かな復極が起った。

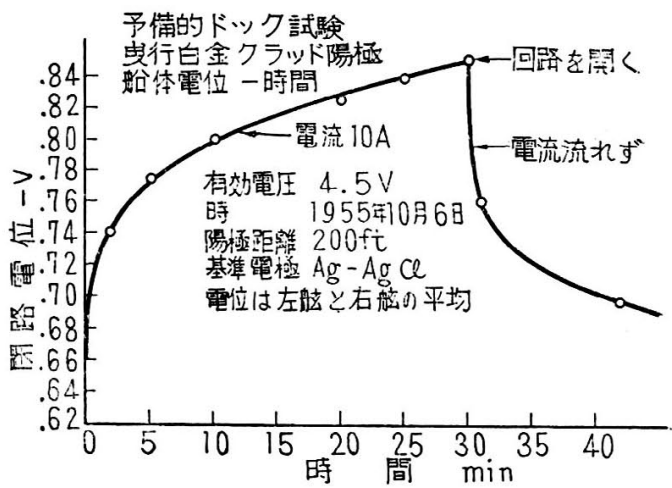

第 6 図 曳行白金陽極を用いた予储実験，船体 電位-時間図

第 2 回試験：1955年 10 月 10 日他のドック試験を行っ た。この試験の目的は静止状態に就いて船体をー $0.82 \mathrm{~V}$ の開路電位まで分極させるために必要な電流を決定する ことであった。船はすべての陸上動力と外部電話回路と 切り離すことにより電気的に絶縁された。ドックで船の 停泊にマニラロープとキ+メル（ロープ防げん材）が使 用された。最初の船体電位の検查は第 5 図に示したよう に船体の周りのいろいろな場所で行われた。第 1 表は種 々の場所で測定された船体の電位を示し平均約 $-0.67 \mathrm{~V}$ である。船体電位で観察された一様性は船体あるいは船 体に取付けてある残留互鉛によってプロペラが部分的に 分極したことを示す。曳行陽極は再び船体から約 $200 \mathrm{ft}$ 猚し, 電線をドックの杭に固定することによって水中に 垂直に浮した。水の試料を取り分析した。結果は pH 7.5 , 比重 $1.025\left(77^{\circ} \mathrm{F}\right)$ 塩分 $3.7 \%$ を示した。比抵抗 は $52^{\circ} \mathrm{F}$ で $25.5 \Omega-\mathrm{cm}$ と計算された。今回は約 $10 \mathrm{hr}$

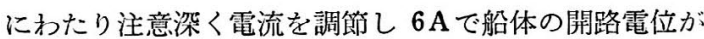
-0.85Vに保たれることを見出した。航行中に記録され た時間-電位図（船首と船尾電極の平均）は第 7 図に示 した。このドック試験では船舶用発電機始動方式による 蓄電力を用いた。静止船を $-0.82 \mathrm{~V}$ の開路分極電位に

第 1 表 ドック試験船体電位

\begin{tabular}{|c|c|c|c|c|c|c|c|c|c|c|c|c|}
\hline \multirow{2}{*}{ 陽極深さ } & \multicolumn{12}{|c|}{ 種 $\&$} \\
\hline & 船 首 & $s_{1}$ & $\mathrm{~S}_{2}$ & $\mathrm{~S}_{3}$ & $\mathrm{~S}_{4}$ & $\mathrm{~S}_{5}$ & 船 尾 & $P_{5}$ & $\mathrm{P}_{4}$ & $P_{3}$ & $\mathrm{P}_{2}$ & $P_{1}$ \\
\hline 水 面 & 0.66 & 0.68 & 0.69 & 0.68 & 0.68 & 0.67 & 0.67 & 0.67 & 0.67 & 0.67 & 0.67 & 0.66 \\
\hline $6 f t$ & 0.66 & 0.66 & 0.68 & 0.68 & 0.68 & 0.67 & 0.66 & 0.67 & 0.67 & 0.67 & 0.67 & 0.67 \\
\hline $12 \mathrm{ft}$ & 0.66 & 0.67 & 0.68 & 0.68 & 0.68 & 0.67 & 0.66 & 0.67 & 0.68 & 0.67 & 0.67 & 0.67 \\
\hline
\end{tabular}


第2表 海上 試 験 船 体 電 位

\begin{tabular}{|c|c|c|c|c|c|c|c|c|c|c|c|c|}
\hline \multirow{2}{*}{ 陽裸深さ } & \multicolumn{12}{|c|}{ 種 々 } \\
\hline & 船 首 & $s_{1}$ & $\mathrm{~S}_{2}$ & $s_{3}$ & $\mathrm{~S}_{4}$ & $\mathrm{~S}_{5}$ & 船 尾 & $\mathrm{P}_{5}$ & $\mathrm{P}_{4}$ & $\mathrm{P}_{3}$ & $\mathrm{P}_{2}$ & $\mathrm{P}_{1}$ \\
\hline 水 面 & 0.72 & 0.72 & 0.72 & 0.74 & 0.73 & 0.71 & 0.69 & 0.72 & 0.73 & 0.72 & 0.73 & 0.70 \\
\hline $6 \mathrm{ft}$ & 0.74 & 0.72 & 0.74 & 0.73 & 0.73 & 0.71 & 0.70 & 0.72 & 0.73 & 0.73 & 0.72 & 0.71 \\
\hline $12 \mathrm{ft}$ & 0.74 & 0.73 & 0.74 & 0.73 & 0.73 & 0.71 & 0.71 & 0.72 & 0.73 & 0.73 & 0.72 & 0.71 \\
\hline
\end{tabular}

注）掵查時間午前10時 35 分 1955 年 10 月 11 日

海水此抵抗 $23.3 \Omega-\mathrm{cm}\left(53.5^{\circ} \mathrm{F}\right)$

基準電極 $\mathrm{Ag} \cdot \mathrm{AgCl} \quad \ominus$ 記号省略

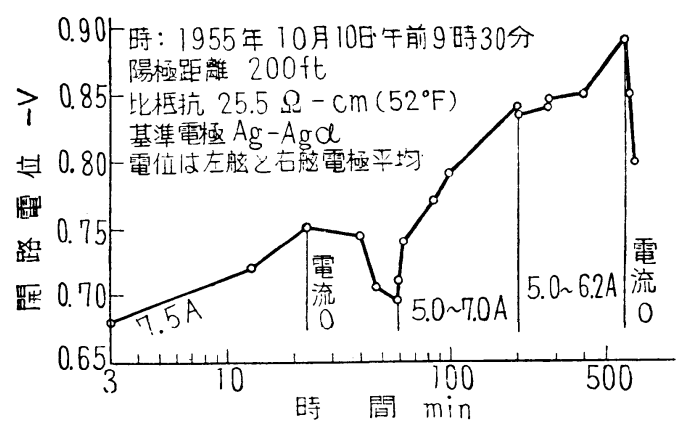

第 7 図 曳行白金クラッド陽極定用いた最後のドック試 験に拈ける船体電位一時間図

維持するための所要電流は $5 \mathrm{~A}$ 程度である。電流が切れ たときに起るゆるやかな復極は分極の時間が増大すると きに船体に持続性の分極膜ができることを示す。船体電 位は船体に密接に取付けられた基準電極で測定された。 遠方の基準電極の読みは $50 \mathrm{mV}$ だけ高い電位を示す。 曳行陽極から電流が流れるとき約 $75 \mathrm{ft}$ は離れた 2 本の 基準電極間での值は海水中の回路において $0.05 \mathrm{~V} の \mathrm{IR}$ 降下を示しこれは近傍と遠方の基準電極間の差異として 説明される。同じ差異は航行試験中にも記録された。

\section{海上試 験}

ドック試験の電流は翌日午前 7 時に切り海上試験の準 備をした。陽極は船舶用発電機配電盤に再び直接接続し た。午前10時 30 分船は約 5 mile 沖に停泊した（すなわ ち風にまかせ漂流だけはしないように静止状態を保っ た)。そこでは水深約 $200 \mathrm{ft}$ であった。船は漸次復極し たが $3.5 \mathrm{hr}$ の期間陽極から電流を流さなかったが船体 の完全な復極は認められなかった。新しい系列の試験を 行うに先だち他の船体電位検査を停泊状態で行った。そ れは第2表に揭げた。海水の試料を採取し分析した。比 抵抗は $53.3^{\circ} \mathrm{F}$ で $23.3 \Omega-\mathrm{cm}$ である。

試験の目的：試験は船体から遠距離に取付けられた曳 行陽極の有効電圧と電流出力間の関係を測定するために 行われた。曳行陽極は船の発電機に接続しキールの下, 船尾から $150 \mathrm{ft}$ に眯垂した。電流は 1.0 から抵抗器の最 大容量の $47 \mathrm{~A}$ まで変化し第 3 図はその結果である。曲 線の大部分は直線でありその匂配は陽極抵抗に等しい。
$2 \mathrm{~V}$ 程度の陽極逆電圧に打勝つまで電流は流れないこと に注意せねばならぬ。更に曲線の上端が平になるのは陽 極での激しい泡だち（酸素と塩素）によってガス膜の抵 抗を生じたためであろら。曳行白金クラット陽極で得ら れる実際的最大電流の決定は行わなかった。

結論：電流出力は本質的に直 線的でありこの試験の $18 \mathrm{~V}$ の範囲で $\mathrm{V}$ 当り平均約 $2.5 \mathrm{~A}$ であった。 $30 \mathrm{~min}$ を 費したこの試験の間，船体の開路電位は約 -0.70〜 $0.89 \mathrm{~V}$ に上昇した。電流をそれから $5 \mathrm{~A}$ に落し $1 \mathrm{hr}$ 保 った。船体の電位は $-0.80 \mathrm{~V}$ で一定に維持されそれは 第 2 回のドック試験の結論を更に強固にした。次に船体 電位に影響があるかどうかを調べるために陽極の深さを $150 \mathrm{ft}$ の深さから水面まで $5 \mathrm{~min}$ 間隔で $50 \mathrm{ft}$ おきに変え た。短い期間陽極と陰極の距離が変化したが電流出力, 有効電圧, 船体電位には変化が認められなかった。明ら かに船体と陽極の距離に対する船体電位分布の変化を調 ベるために長期間の試験が必要である。

\section{航行中試験}

試験目的：試験は $-0.82 \mathrm{~V}$ の防食電位を維持するた めの所要電流に対する船速の影響を決定するために行わ れた。航行船について一連の電位, 電流測定を行った。 そのテータは第 8 図に示す。陽極は $200 \mathrm{ft}$ 後方に, 2 本 の基準電極は $50 \mathrm{ft}$ 後方に曳行した。時間0 minで出発し 約 $5 \mathrm{~A}$ の電流で 3 ノットのときに平均 $-0.79 \mathrm{~V}$ の船体電 位を維持した。 $4 \mathrm{~min}$ 後船速を 6 ノットに増した。電流 は変化しなかった。次の $19 \mathrm{~min}$ 間開路電位は $-0.79 か$ らー0.77Vに低下した。速度はそのとき9ノットに増し たが $4 \mathrm{~min}$ の間電力損失によって $-0.735 \mathrm{~V}$ に低下した。 電力が回復して電流は $9 \mathrm{~A}$ に増し $21 \mathrm{~min}$ 保った。船体 電位は船尾で $-0.75 \mathrm{~V}$ 船首で $-0.80 \mathrm{~V}$, 平均 $-0.775 \mathrm{~V}$ に上昇した。電流を再び $15 \mathrm{~A}$ に増加した。10 min 後船 首電位は $-0.85 \mathrm{~V}$ に上昇し船尾で $-0.80 \mathrm{~V}$ になった。 $-0.825 \mathrm{~V}$ の平均電位が第 8 図に示してある。それから 電流を切り速度は 9 ノットに維持した。約 $50 \mathrm{~min}$ 間に 船体電位は平均 $-0.685 \mathrm{~V}$ に落ちた。船体を更に復極さ せるために導線を逆につないだ。船体を陽極とし曳行白 金棒を陰極とした。2 $\mathrm{min}$ 後逆電流を $15 \mathrm{~A}$ 流した。導線 を再び正常状態につないだ。開路電位は平均 $-0.665 \mathrm{~V}$ 


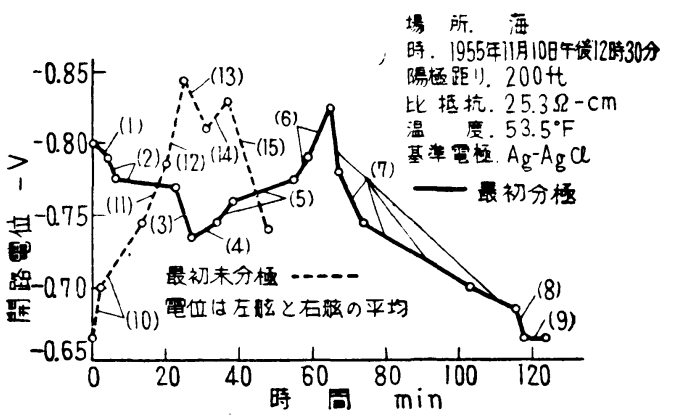
(1) $5.1 \mathrm{~A}-3$ /,
(6) $15.3 \mathrm{~A}-9$ ) ット
(10) $15.2 \mathrm{~A}-9$ ノット
(2) $5.1 \mathrm{~A}-6$ )
(7) $0.0 \mathrm{~A}-9 /$ \%
(11) $19.5 \mathrm{~A}-9 / \%$ /
(3) $0.0 \mathrm{~A}-6$, \%
(4) $5.1 \mathrm{~A}-9$ )
(5) $9.3 \mathrm{~A}-9$ ),
$15.5 \mathrm{~A}-9$ ノッ 極性反対
(12) $19.5 \mathrm{~A}-6$ / ット
(19) $9.9 \mathrm{~A}-6$ / $\circ$
(9) $0.0 \mathrm{~A}-9$ ノット (14) $9.9 \mathrm{~A}-3$ ノッ
(115 $0.0 \mathrm{~A}-8$ ) ゥ

第 8 図曳行白金陽極を用いた航行試験 種々の状態に 対する船体電位-時間図

に落ちた。それ以上の復極は次の $6 \mathrm{~min}$ 間では認められ ず船速は 9 ノットに維持し電流は流さなかった。電流は 再び $15 \mathrm{~A}$ を適用した。14min 後船体電位は平均 -0.745 Vに上昇した。それから電流を $19.5 \mathrm{~A}$ にあげ $6 \mathrm{~min}$ 経 過後船体電位は平均 $-0.785 \mathrm{~V}$ に達した。船を 6 ノット の速度に低下させると電流 $19.5 \mathrm{~A}$ で電位は $-0.845 \mathrm{~V}$ に上昇した。電流を約 $10 \mathrm{~A}$ に減らすと $6 \mathrm{~min}$ 間で平均 電位は $-0.81 \mathrm{~V}$ に落着いた。速度を 3 ノットに減らし 電流は $10 \mathrm{~A}$ に保った。この結果船体電位は $6 \mathrm{~min}$ 以内

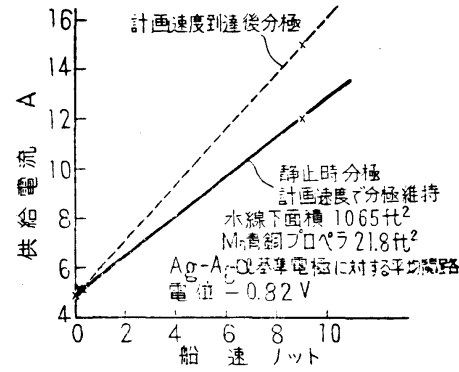

第 9 図 曳行白金クラッド陽 極を用いたとき船速に対す る船体分極所要電流概略值
に $-0.83 \mathrm{~V} に$ 上昇した。種々 の速度で船体開 路電位を一 0.82 Vに維持するた めの所要電流值 を第 9 図に示し た。

結論：既に分 極している船で は速度 9 ノット で分極を維持す るために必要な電流は静止船に対して必要な電流の 2 倍 強である。9ノットの速度で航行中の船を分極させるに 必要な電流は（静止時は分極せず）静止状態下での分極 に必要な電流の 3 倍を要する。曳行陽極々戋行電極は 9 ノットまでの速度では急な変動をしたり振動することな く満足に動作した。 $47 \mathrm{~A}$ までの電流出力で使用するとき には目に見えるような陽極の消耗は起らなかった。

\section{総 括 と結 論}

曳行白金陽極は港や海上で比較的簡単に小さな船の陰 極防食に能力を示した。船体の均一な分極は静止船にお
いて $5 \mathrm{~A}$ の電流出力でまた 9 ノットで航行中のときには $12 \mathrm{~A}$ で達成される。白金陽極は使用中きれいに保たれ電 流出力と有効電生間の直線的関係によって明らかなよう にその表面に抵抗皮膜は形成されない。就役状態下の白 金陽極曳行の容易さと高い操作電流容量のためにこの型 式を容易にもっと大きな船に応用できる。

\section{詇}

曳行白金クラッド陽極は軍艦と商船への適用を考える ベきである。それは碇泊所における高速軍艦の作業や機 動には適しないが特務艦や商船には役立つ。曳行白金ク ラッド陽極の電流出力の上限はその大きさと利用できる 有効電生によってのみ規制される。これは就行船に対し て知られている最小の費用でもっとも応用のきく電気防 食法でありかつその装置と保守が比較的簡単であるよう に思 5。 $100 \mathrm{~A}$ の電流容量の曳行陽極電気防食系の費用 は（大洋航行貨物船を防食する能力がある）1000ドルを 超えない。同容量の船体取付陽極を用いた場合は少なく とも10倍以上の費用がかかる。白金陽極の寿命は機械的 破壞を除いて船の就役寿命より長いと予想される。

\section{将来の計 画}

将来の海上試験ではもっと大きな速い船に対して, 大 きな船体面積の分極に括ける陽極効果と高速での陽極曳 行特性を確かめよと計画している。この試験がうまく ゆけば船体に適当に取りつけられたパイプから陽極を曳 行し自動的に引き上げ得るように計画を進める予定であ る。

\section{交献}

1) B. H. Tytell et al : J. Soc. Naval Engrs, 701 704 (1956) Nov.

2) L. J. Waldron et al: The Performance of a Cathodic Protection System on the USS SUMNER (DD 692). Dec. 1953-Jan. 1955, NRL Report 4635, 30 Sept. 1955

3) L. J. Waldron \& M. H. Peterson: The Performance of a Cathodic Protection Systems on the USS INGRAHAM. (DD 694). Dec. 1953-Jan.1955, NRL Report 4636, 30 Sept. 1955.

4) E.E. Nelson: The Cathodic Protection System on the USS AMBERJACK (SS 522). Mar. 1953 to Feb. 1955, NRL Report 4525, 6 May 1955 .

5) K. N. Bernard et al : Corrosion, 9, $246-250$ (1953) Aug.

6) E.R. Shepard et al : Corrosion, 6, 362 (1950) Nov.

7) T.A. Edison : Process \& Arrangement for Protecting Ship Bottoms by Means of Electricity. Ger. Pat 57293, 14 Sept. 1890; Eng. Pat. No.13971, 5, Sept. 1890.

8) L. Pode: Tables for Computing the Equilibrium Confi. guration of a Flexible Cable in a Uniform Stream. Taylor Model Basin Report 687, Mar. 1951.

9) R.C. Whitman: "Trailing Platinum-clad Anode, Dockside and Underway Tests," Portsmouth Naval Shipyard, Technical Report No. T-548, Feb. 1955

10) D. E. Lincoln : ibid, Technical Report No.T-548. Supplement 1, Nov. 1955.

11) I. D. Gessow : Corrosion, 12, 101t (1956) Mar. 